\title{
KOMUNIKASI POLITIK PEMERINTAH KABUPATEN BANDUNG BARAT DALAM MENYOSIALISASIKAN MASYARAKAT EKONOMI ASEAN (MEA)
}

\author{
Evie Ariadne Shintadewi dan Benazir Bona Pratamawati \\ Fakultas Ilmu Komunikasi Universitas Padjadjaran \\ E-mail: evie@unpad.ac.id
}

\begin{abstract}
ABSTRAK. Konsekuensi berlakunya Masyarakat Ekonomi Asean (MEA) bagi negara Indonesia adalah keniscayaan menghadapi bebasnya arus perdagangan barang, jasa, pasar tenaga kerja dan investasi dengan negara ASEAN lainnya. Persoalan utama adalah kesiapan pemerintah Indonesia, khususnya pemerintah daerah mempersiapkan masyarakat menghadapi tantangan sekaligus peluang besar MEA. Kesiapan ini dapat lebih terarah jika pemerintah daerah melaksanakan fungsi komunikasi politiknya dengan secara optimal menyosialisasikan MEA. Sebagai fase baru kehidupan perekonomian negara Indonesia di tingkat Kawasan, mengkomunikasikan [MEA secara optimal menjadi tantangan tersendiri karena tentu akan berdampak pada masyarakat daerah. Penelitian ini bertujuan untuk menggambarkan bagaimana seharusnya pemerintah KBB mengkomunikasikan MEA. Menggunakan metode studi kasus penelitian ini memperoleh data melalui wawancara mendalam, sudi dokumentasi dan observasi serta focuss Group Discussion. Hasil penelitian menunjukan bahwa pemerintah Kab. Bandung Barat belum melaksanakan fungsi komunikasi politiknya dalam menyosialisasikan MEA kepada masyarakat secara optimal. Hal ini dapat dilihat dari belum adanya strategi khusus untuk menyosialisasikan MEA kepada masyarakat Kab. Bandung Barat. Upaya yang dilakukana baru sebatas menyelipkan content MEA di dalam beberapa kegiatan yang melibatkan masyarakat. Media komunikasi yang digunakan masih terbatas pada press release yang disampaikan kepada kelompok kerja wartawan serta dukungan kepada dinas terkait tentang penggunaan fasilitas IT oleh Dinas Komunikasi \& Informasi berupa website. Mencermati hal ini, maka dari hasil penelitian ini disarankan agar KBB membentuk tim khusus yang menangani pengelolaan komunikasi lintas dinas, sehingga dapat memiliki strategi dan formulasi spesifik untuk mengkomunikasikan MEA kepada seluruh stakeholder
\end{abstract}

Kata kunci: Strategi, Komunikasi Politik Pemerintah, Sosialisasi, Masyarakat Ekonomi Asean (MEA).

\section{GOVERNMENT POLITICAL COMMUNICATION OF KABUPATEN BANDUNG BARAT IN SOCIALIZING ASEAN ECONOMICS COMMUNITY (AEC)}

\begin{abstract}
The consequences of ASEAN Economic Community (AEC) for Indonesia are the inevitability of facing the free flow of trade in goods, services, labor markets and investment with other ASEAN countries. The main problem that arises is the readiness of government, especially the local government to prepare the community facing the challenges as well as the great opportunities of AEC. This readiness can be more focused if local governments implement their political communication function optimally. As a new phase of Indonesia's economic life at the Region level, communicating the AEC becomes a challenge because it will certainly have an impact on the local community. This study aims to describe how Government of KBB should be communicate in preparing the community facing the AEC. Using case study methode, we obtained data through in-depth interviews, documentation study, observation and Focuss Group Discussion. The results showed that the government of West Bandung regency has not implemented its political communication function in socializing AEC to society optimally. This can be seen from the absence of specific strategies to socialize AEC to the community West Bandung. Efforts that are done just to insert the content of AEC in some activities that involve the community. The communication media used is still limited. Observing this, it is suggested that KBB establish a special team that handles cross-agency communication management, so it can have specific strategies and formulations to communicate the AEC to all stakeholders.
\end{abstract}

Key words: Government Political Communication, Asean Economic Community (AEC) socialization.

\section{PENDAHULUAN}

Sejak 1 Januari 2016 Indonesia mulai memasuki fase baru tatanan kehidupan bermasyarakat di tingkat kawasan yakni dengan mulai efektifnya ASEAN Economic Community (AEC) atau yang lebih dikenal dengan Masyarakat Ekonomi ASEAN (MEA). Awal Januari 2016 menandai langkah baru kesepuluh negara anggota kawasan ASEAN dalam bidang kerjasama ekonomi kawasan. Indonesia, Malaysia, Filipina, Singapura, Thailand, Brunei, Kamboja, Laos, Myanmar dan Vietnam-yang telahmempersiapkan dirinya berusaha memenuhi AEC Blueprint 2007 dalam menyongsong era baru kebijakan ekonomi tingkat kawasan tersebut.
Konsekuensi berlakunya MEA yang utama adalah Indonesia harus membuka perdagangan barang, jasa, dan pasar tenaga kerja dengan negaraASEAN lainnya. Namun demikian, sejak tahun 2016 hingga pertengahan 2018 ini, perlu ada identifikasi apa saja yang sudah Indonesia lakukan dalam mempersiapkan masyarakat menghadapi MEA? Bagaimana kesiapan pemerintah Indonesia, khususnya Pemerintah Daerah, dalam menghadapi MEA? Apakah masyarakat di daerah menyadari tantangan besar yang harus mereka hadapi, misalnya dalam persaingan dunia usaha dan ketenagakerjaan dengan adanya MEA ini? apakah masyarakat menyadari dampak MEA dalam tatanan kehidupan bermasyarakat sehari-hari? Bagaimana pemerintah daerah melaksanakan fungsi 
komunikasi politiknya dalam menyosialisasikan berbagai kebijakannya pada era MEA? dan berbagai pertanyaan lain yang muncul sejalan dengan berlangsungnya MEA ini.

Secara ideal, pemerintah daerah selayaknya ikut menyiapkan diri dalam menghadapi MEA, karena sebagai kebijakan internasional yang lahir dari sebuah bentuk perjanjian internasional, keberadaan MEA akan berdampak bagi kehidupan masyarakat negara anggota perjanjian tersebut. Mereka yang akan terkena dampak tersebut tidak hanya para pelaku usaha besar, namun juga pelaku usaha kecil, termasuk daerah-daerah yang baru lahir sebagai kota atau kabupaten hasil pemekaran seperti Kabupaten Bandung Barat (KBB). Pemerintah KBB sudah selayaknya mengantisipasi dampak ini, salah satunya dengan mengeluarkan kebijakan yang berlandaskan pada kebijakan pemerintah pusat terkait MEA. Selayaknya, segera setelah kebijakan dibuat, maka pemerintah daerah perlu menyosialisasikannya kepada seluruh stakeholders termasuk kepada masyarakat luas guna menyiapkan masyarakat dalam menghadapi fase baru kehidupan perekonomian negara Indonesia di tingkat kawasan.

Merujuk pada kebijakan Pemerintah Provinsi Jawa Barat tentang perlunya pemda melakukan sosialisasi MEA, maka pemerintah daerah KBB yang merupakan salah satu dari 27 kota kabupaten di Jawa Barat, perlu mengeluarkan kebijakan komunikasi politik tertentu dalam rangka menyosialisasikan pemberlakuan MEA guna menyiapkan seluruh stakeholders menghadapi fase baru tatanan perekonomian bangsa saat ini. Hal ini perlu dilakukan mengingat setiap kebijakan internasional dalam tingkatan regional senantiasa berdampak langsung pada kehidupan sehari-hari masyarakat. Kehadiran MEA di tengah-tengah masyarakat harus diikuti dengan pemahaman dan perubahan cara berpikir dalam menghadapi persaingan dunia usaha yang pada gilirannya menyentuh seluruh aspek kehidupan.

Hasil penelitian menunjukkan pemerintah $\mathrm{KBB}$ masih belum memiliki kebijakan yang khusus yang dibuat untuk mengkomunikasikan tantangan MEA kepada masyarakat luas. Hal ini ditunjukkan dengan belum adanya kegiatan atau strategi komunikasi yan spesifik dalam menyosialisasikan MEA secara optimal, baik oleh Dinas Komunikasi dan Informasi maupun oleh bagian Humas KBB. Padahal, jika mencermati peluang yang dimiliki negara Indonesia sebagai negara dengan pasar terbesar di ASEAN, sesungguhnya setiap daerah memiliki peluang yang juga sama besarnya dengan pasar yang ada. Langkah utama yang perlu diperhatikan oleh pemerintah adalah menyiapkan masyarakat menghadapi fase baru ini. Tidak hanya terfokus pada masyarakat pelaku usaha, melainkan pada masyarakat secara umum.

Hal inilah yang perlu mendapat perhatian pemerintah daerah, termasuk pemda KBB. Upaya ini dapat dilakukan dengan membangun sebuah strategi komunikasi politik yang tepat dalam rangka menciptakan pemahaman dan perubahan cara berpikir masyarakat umum dalam menghadapi era pasar bebas di tingkat kawasan ASEAN ini. Strategi komunikasi politik yang tepat dapat menyiapkan masyarakat dengan pemahaman dan sikap kompetitif yang senantiasa waspada dalam menghadapi era baru MEA.

Penelitian untuk mengetahui gambaran bagaimana strategi komunikasi politik yang diterapkan oleh pemerintah daerah KBB dalam menyiapkan masyarakat menghadapi dampak MEA cukup penting agar dapat memperoleh gambaran bagaimana model strategi komunikasi politik pemerintah daerah KBB dalam menghadapi MEA. Dengan demikian, masalah yang ingin dikaji dalam penelitian ini dirumuskan sebagai berikut: Bagaimana Komunikasi Politik Pemerintah Kabupaten Bandung Barat Dalam Menyosialisasikan Masyarakat Ekonomi Asean (MEA)?

Secara rinci pertaanyaan penelitian sebagai berikut:

1. Bagaimana Pemerintah KBB mempersiapkan masyarakat dalam menghadapi MEA?

2. Bagaimana pemerintah KBB membuat strategi sosialisasi khusus terkait Masyarakat Ekonomi Asean?

3. Bagaimana Peran Dinas Komunikasi dan Informasi dalam mengoptimalkan dukungan bagi dinas-dinas lain terutama dengan menggunakan teknologi informatika?

4. Media komunikasi dan sosialisasi apa yang digunakan oleh pemerintah KBB dalam menyosialisasikan MEA?

5. Bagaimana pemda KBB menyosialisasikan Content MEA di kalangan internal aparat pemda KBB tentang segala sesuatu menyangkut MEA?

Berdasarkan latar belakang masalah yang telah dipaparkan sebelumnya, maka penelitian ini menggunakan paradigma riset deskriptif kualitatif dengan metode Studi Kasus. Adapun tujuan penelitian ini adalah: 1. Secara akademik, bertujuan untuk mengetahui bagaimana penggunaan konsep dan teori komunikasi politik pada pemerintah daerah di Kabupaten Bandung Barat.

2. Secara practtical, untuk mengetahui bagaimana pemda KBB menyiapkan perangkat daerahnya dalam merancang strategi komunikasi melaksanakan tantangan MEA.

3. Untuk mengetahui strategi komunikasi politik yang dirancang oleh pemda KBB dalam menyosialisasikan kebijakan-kebijakannya pada era MEA.

Tujuan penelitian ini diharapkan menghasilkan model yang dapat diterapkan secara konkrit oleh pemerintah KBB dalam membuat kebijakan strategis dalam konteks MEA. Adapun konteks penelitian tentang komunikasi politik pemerintah daerah, terutama daerah yang baru berdiri sebagai akibat pemekaran seperti Kabupaten Bandung Barat.

Artikel ini merupakan hasil riset yang didanai oleh HIU skema RFU dan berusaha mengkaji komunikasi 
pemerintah KBB tentang MEA dengan menggunakan konsep-konsep komunikasi politik. Paparan berikut menjelaskan sedikit tentang pengertian komunikasi politik pemerintah (government political communication).

\section{Komunikasi Politik}

Komunikasi politik merupakan sebuah bidang kajian ilmu yang menggabungkan dua unsur besar keilmuan, yakni ilmu komunikasi dan ilmu politik. Berbicara mengenai definisi dari masing-masing istilah maka dapat dimulai dari definisi komunikasi. Menurut (Nimmo, 2005, p. 5) bergantung pada titik pandanganya, komunikasi adalah: pengalihan informasi untuk memperoleh tanggapan; pengkoordinasian makna antara seseorang dan khalayak; saling berbagi informasi, gagasan, atau sikap; saling berbagi unsur-unsur perilaku, atau modus kehidupan, melalui perangkat-perangkat aturan; "penyesuaian pikiran, penciptaan perangkat simbol bersama di dalam pikiran peserta - singkatnya, suatu pengertian, suatu peristiwa yang dialami secara internal, yang murni personal yang dibagi dengan orang lain; atau pengalihan informasi dari satu orang atau kelompok kepada yang lain, terutama dengan menggunakan simbol. Pada akhirnya, (Nimmo, 2005, p. 6) menyimpulkan komunikasi adalah proses interaksi sosial yang digunakan orang untuk menyusun makna yang merupakan citra mereka mengenai dunia (yang berdasarkan itu mereka bertindak) dan untuk bertukar citra itu melalui simbol-simbol.

Sementara itu, berkaitan dengan definisi politik, ilmuwan politik Mark Roelofs dalam (Nimmo, 2005, p. 8) menyatakan politik adalah pembicaraan atau lebih tepat, kegiatan berpolitik adalah berbicara. Roelofs juga menekankan bahwa politik tidak hanya pembicaraan, juga tidak semua pembicaraan adalah politik.

Pengertian komunikasi politik menurut (McNair, 2007, p. 4) sebagai sebuah kegiatan komunikasi mengenai politik yang disengaja, yang di dalamnya meliputi: (1) semua bentuk komunikasi yang dilakukan oleh politisi dan aktor politik lainnya yang bertujuan untuk mencapai hasil tertentu; (2) komunikasi yang ditujukan kepada aktor-aktor politik tersebut oleh non-politisi, seperti para pemilih dan kolumnis surat kabar; dan (3) komunikasi tentang para aktor politik tersebut dan aktivitas mereka yang dimuat atau dipublikasikan dalam berita, editorial surat kabar, maupun bentuk diskusi politik lainnya yang menggunakan media. McNair juga berpendapat bahwa komunikasi politik tidak hanya meliputi bahasa verbal ataupun pernyataan tertulis, melainkan juga alat-alat visual lainnya seperti pakaian, dandanan, gaya rambut, desain logo, yakni semua elemen komunikasi yang dapat dikatakan membentuk sebuah "citra" atau identitas politis.

Adapun komunikasi politik pemerintah (government political communication), secara spesifik dikemukakan Stephen Hess dalam (Hamilton, 1996) the government/press connection: press officer and their office, bahwa fungsi pemerintah di alam demokrasi ini adalah untuk menyebarkan informasi tentang jalannya pemerintahan itu sendiri.

Lebih jauh, (Millett) menyatakan, komunikasi di lembaga pemerintahan mencakup kegiatan-kegiatan sebagai berikut:

a) Mempelajari apa yang public inginkan dan aspirasi mereka. (learning about public desire and aspiration)

b) (menasihati public tentang apa yang seharusnya diinginkan. (advising the public about what is should desire)

c) Memastikan mekanisme kontak yang memuasakan antara public dengan para staf manajemen pemerintah (ensuring satisfactory contact between public and management officials)

d) Menginformasikan kepada public tentang apa yang sedang dilakukan oleh pemerintah (Informing the public about what an agency is doing).

Dari konsep diatas, dapat dipahami bahwa dasar pemikiran komunikasi pemerintah yang paling mendasar adalah 1) publik punya hak untuk tahu dan 2) adanya kebutuhan pemerintah sendiri untuk mendapatkan input dari publik. Oleh karenanya, secara umum tujuan utama Komunikasi Pemerintahan, yaitu:

1) Memberi tahu warga negara mengenai kebijakan pemerintah, DPRD , dinas-dinas, serta aktivitasnya sehari-hari.

2) Memberi kesempatan kepada warga menyatakan pandangannya mengenai proyek-proyek yang penting / baru sebelum keputusan dijatuhkan oleh pejabat-pejabat yang dipilih.

3) Untuk memberikan penerangan kepada warga negara mengenai cara-cara kerja perangkat pemerintah dan memberikan informasi kepada mereka mengenai hak-hak dan kewajibannya

4) Untuk meningkatkan rasa bangga sebagai warga negara ( (Black, 2000, p. 173)

Tugas pemerintah dalam mengkomunikasikan kebijakan adalah mengangkat dan memberi tahu halhal yang tidak diketahui padahal seharusnya diketahui, ataupun mempopulerkan hal-hal yang tidak populer padahal hal tersebut seharusnya populer. Syarat yang harus dipenuhi dalam mempopulerkan hal-hal yang harus dipopulerkan ini adalah harus ada data atau fakta. Oleh karenanya, tugas utama bidang komunikasi Pemerintahan mengumpulkan fakta yang dibutuhkan melalui riset (misal riset pemetaan pemuka pendapat).

Dari paparan tentang komunikasi politik pemerintah tersebut, peneliti mencoba menggunakan konsep-konsep tersebut sebagai landasan analisis atas bagaimana seharusnya pemerintah KBB menginformasikan dan juga menasihati public terkait peluang dan tantangan MEA. 


\section{Strategi Komunikasi}

Sally J Patterson dalam bukunya "Strategic Communication", (Patterson, 2009) mengemukakan pentingnya penyusunan strategi komunikasi untuk menghadapi suatu perubahan dan tantangan, karena:

$\checkmark$ It is the key to successful social change.

$\checkmark$ Its mission driven, audience focused and action oriented.

$\checkmark$ It is the art of expressing ideas combined with the science of transmitting information.

$\checkmark$ It is crafting the message so that it motivates target audiences to act in desired manner.

Pemilihan media komunikasi merupakan strategi komunikasi pemerintah, seperti dikutip oleh Elfe Mingkid dalam tulisannya yang dimuat di jurnal Sosiohumaniora, Volume 18 No. 3 November 2015: 188 - 192 bahwa komunikasi merupakan cara yang dipergunakan dalam mengadakan hubungan dengan orang lain baik di dalam maupun di luar organisasi yang dalam kategori komunikasi metode lisan dan tulisan. Secara konseptual, pemahaman akan media komunikasi dapat terlihat dari pemikiran Harold Laswell dalam Mingkid (2012) In which channel yaitu saluran atau media yang digunakan d alam proses komunikasi apakah langsung atau tatap muka dan sebagainya; Siagian (1997 :122) bahwa poses komunikasi setidaknya melibatkan saluran, ialah alat yang digunakan oleh komunikator untuk menyampaikan pesan; Onong $(1986 ; 6)$ unsurunsur komunikasi antara lain adalah media yaitu sarana atau saluran yang mendukung pesan bila komunikan jauh tempatnya atau banyak jumlahnya.

MEA jelas merupakan suatu perubahan yang melahirkan tantangan baru, apalagi situasi masyarakata di era digital saat ini dapat dikatakan berada pada situasi serba berfungsi cepat, kacau, dan kompleks. Banyak orang merasa kewalahan dengan campuran media, pemboman pesan, dan intensitas emosi, promosi dan proklamasi dari pengiklan, pakar media, dan minat komersial dan nonprofit. Maka dalam situasi ini memformulasikan strategi komunikasi yang tepat bagi pemerintah daerah KBB menjadi sebuah keniscayaan.

\section{Masyarakat Ekonomi ASEAN (MEA)}

ASEAN Economic Community (AEC) atau Masyarakat Ekonomi ASEAN (MEA) yang mulai diberlakukan pada akhir tahun 2015 menjadikan kawasan ASEAN sebagai pasar tunggal dan terbuka yang berbasis produksi; dengan pergerakan bebas arus barang, jasa, investasi, modal, dan tenaga kerja. Dan mulai tahun 2016 Indonesia menghadapi tantangan simultan baik tantangan eksternal maupun internal, sebagai berikut:

Tantangan eksternal:

1. Tingkat Persaingan Perdagangan Semakin Ketat

- Tingkat persaingan yang semakin terbuka dan tajam dalam pemasaran barang dan jasa, yang bermula dengan penerapan ASEAN Free Trade Area (AFTA) pada tahun 1992 yang implementasinya dilakukan secara bertahap sejak 1 Januari 1993 sampai dengan tahun 2002.

- Perdagangan intra kawasan ASEAN meningkat sangat tajam sejak diberlakukannya AFTA. Sementara itu, Indonesia hanya memberikan kontribusi sebesar 14,6\% terhadap ekspor intra kawasan ASEAN (2011)

2. Neraca Perdagangan Indonesia dengan ASEAN mengalami defisit yang semakin besar.

3. Peningkatan Daya Tarik Investasi

$\circ$ Di sisi investasi langsung masuk (FDI inflow) ke kawasan ASEAN, Indonesia terlihat menjadi salah satu negara ASEAN kedua yang diminati oleh investor, setelah Singapura.

- Dari total investasi langsung yang masuk ke kawasan ASEAN pada tahun 2011, 16,3\% ditujukan ke Indonesia; dimana proporsi ini meningkat dari tahun-tahun sebelumnya.

○ Ke depan, perlu ditingkatkan daya tarik investasi di Indonesia agar dapat bertahan sebagai negara tujuan investasi di ASEAN

Tantangan Internal:

a. Stakeholders banyak yang masih belum memahami MEA, baik di kalangan pengusaha, akademisi, aparat pemerintah (pusat $\&$ daerah). Bahkan survey pada 399 responden di lima kota besar tahun 2011 yang dilakukan oleh Benny \& Kamarulnizam menyatakan hanya 39\% stakeholder yang mengetahui tentang MEA, padahal 96\% menyatakan mengetahui ASEAN. $66 \%$ menyatakan belum pernah mendapat penjelasan dari pemerintah tentang MEA.

b. Belum siapnya daerah menghadapi MEA, hal ini terlihat dari masih banyaknya pemda yang belum mempersiapkan regulasi dan program kerja terkait MEA serta masih belum terkelolanya koordinasi antara pemerintah pusat dan daerah dalam menyosialisasikan MEA.

c. Tingkat Pembangunan yang bervariasi antar daerah

d. Kondisi Tenaga Kerja dan Indeks Pembangunan Manusia. Menurut Asian Productivity Organization (APO), dari setiap 1.000 tenaga kerja Indonesia hanya ada sekitar 4,3\% yang terampil, sedangkan Filipina $8,3 \%$, Malaysia $32,6 \%$, dan Singapura 34,7\%. Indeks Pembangunan Manusia untuk Indonesia berada pada peringkat ke-6 di ASEAN

Dari paparan tentang MEA ini dapat dikatakan bahwa setiap pemerintah daerah memiliki kepentingan yang cukup signifikan untuk mengantisipasi tantangan eksternal dan internal tersebut. Bahkan seperti dinyatakan Razak \& Elyta dalam artikel mereka yang dimuat di Jurnal Sosiohumaniora Vol 19 no 3 tahun 2017, bahwa MEA yang terdiri dari negara-negara anggota 
Association of South East Asia Nation (ASEAN) dibentuk untuk dijadikan sebagai pasar produksi tunggal di kawasan ASEAN. Selain itu terbentuknya ASEAN agar aktivitas perdagangan menjadi lebih dinamis dan mampu bersaing. Kerjasama ASEAN memperkokoh hubungan antar negara yang didalamnya terdapat inisiatif ekonomi.

\section{METODE}

Penelitian ini menggunakan pendekatan deskriptif kualitatifdengan metode studi kasus. Pendekatan kualitatif dipandang relevan dengan masalah yang ingin diteliti, yakni mengkaji dan menganalisis secara mendalam kesiapan serta strategi komunikasi politik pemda KBB dalam menyiapkan masyarakatnya menghadapi MEA.

Penelitian kualitatif merupakan metode-metode untuk mengeksplorasi dan memahami makna yang - oleh sejumlah individu atau sekelompok orang - dianggap berasal dari masalah sosial atau kemanusiaan. Proses penelitian kualitatif ini melibatkan upaya-upaya penting, seperti mengajukan pertanyaan-pertanyaan dan prosedurprosedur, mengumpulkan data yang spesifik dari para partisipan, menganalisis data secara induktif mulai dari tema-tema yang khusus ke tema-tema umum, dan menafsirkan makna data. Laporan akhir untuk penelitian ini memiliki struktur atau kerangka yang fleksibel. Siapapun yang terlibat dalam bentuk penelitian ini harus menerapkan cara pandang penelitian yang bergaya induktif, berfokus terhadap makna individual, dan menerjemahkan kompleksitas suatu persoalan (Creswell, 2012, pp. 4-5).

Dalam konteks riset di KBB ini, pendekatan kualitatif diharapkan sejalan dengan tujuan penelitian yakni untuk mengetahui secara cermat dan mendalam aktivitas yang dilakukan olehpemdaKBBdalammenghadapiMEA dan strategi komunikasi politik dalam menyosialisasikan kebijakan-kebijakannya. Adapun metode penelitian yang digunakan adalah metode studi kasus. (Stake, 1995) dalam (Creswell, 2012, p. 20) menyatakan bahwa Studi Kasus merupakan strategi penelitian di mana di dalamnya peneliti menyelidiki secara cermat suatu program, peristiwa, aktivitas, proses, atau sekelompok individu. Kasus-kasus dibatasi oleh waktu dan aktivitas, dan peneliti mengumpulkan informasi secara lengkap dengan menggunakan berbagai prosedur pengumpulan data berdasarkan waktu yang telah ditentukan.

Mengacu pada pengertian tersebut, maka peneliti berasumsimetode studi kasus cukup tepat digunakan untuk menyelidiki secara cermat dan mendalam aktivitas yang dilakukan oleh pemda KBB dalam menghadapi MEA dan strategi komunikasi politik dalam menyosialisasikan kebijakan-kebijakannya. Penggunaan metode studi kasus ini dengan landasan bahwasannya pemberlakuan MEA merupakan sebuah kegiatan dengan rentang waktu yang jelas dan merupakan sebuah program yang baru pertama kali diberlakukan dalam skala internasional di tingkat kawasan. Maka penting untuk mengkaji dan menganalisis kegiatan komunikasi politik yang dilakukan pemerintah dalam menghadapi era atau fase baru tatanan kehidupan bermasyarakat Indonesia saat ini. Hal ini dapat dimulai dengan mengkaji dan menganalisis aktivitas komunikasi politik yang terjadi di tingkat daerah, dalam hal ini pemda KBB.

Data yang dibutuhkan dalam penelitian ini terbagi ke dalam dua jenis data, yakni data primer dan data sekunder. Data primer merupakan data yang didapatkan langsung dari subjek penelitian, yang dilakukan dengan melakukan wawancara mendalam terhadap subjek penelitian. Kegiatan wawancara mendalam yang dilakukan merupakan wawancara terstruktur dengan instrumen penelitiannya berupa daftar pertanyaan terstruktur yang telah disiapkan sebelumnya.

Sedangkan data sekunder didapatkan dari sumbersumber lain yang relevan, seperti dokumen-dokumen yang berkaitan dengan kegiatan atau program komunikasi politik pemda KBB dalam menghadapi MEA. Studi dokumentasi berupa peraturan daerah, suat perintah, suat keputusan dan bisa juga berupa artikel atau tulisan yang dapat ditemukan di media massa. Selain itu, data sekunder juga didapatkan melalui kegiatan observasi yang dilakukan secara langsung dalam setiap aktivitas atau program komunikasi politik yang dilakukan oleh pemda KBB.

Subjek penelitian ini adalah para pejabat pembuat keputusan di tingkat kabupaten yang memiliki peranan kuat dalam hal pembuatan kebijakan dan pembuatan keputusan sehubungan dengan berlakunya MEA, yang meliputi kepala daerah KBB (Bupati \& Wakil Bupati), Kepala Dinas Komunikasi dan Informasi beserta tim, dan Kepala Bagian Hubungan Masyarakat beserta tim, ketua DPRD serta pihak-pihak yang dianggap memiliki andil yang besar dalam pelaksanaan aktivitas komunikasi politik pemda KBB sehubungan dengan pemberlakuan MEA.

Sementara itu, objek penelitian ini adalah kegiatan atau program yang dilakukan oleh pemda KBB dalam menghadapi MEA dan strategi komunikasi politik yang dilakukan guna menyosialisasikan berbagai kebijakan dalam angka mempersiapkan masyarakat menghadapi MEA.

Lazimnya penelitian deskriptif kualitatif, sample penelitian ditentukan dengan metode purposive sampling, yaitu memilih orang tertentu sebagai informan yang telah ditentukan terlebih dahulu kriterianya, dimana dalam penelitian ini, kriteria informan mencakup:

1. Kepala Daerah atau wakilnya (Bupati /wakil bupati)

2. Pejabat di lingkungan pemda KBB yang setidaknya memiliki kewenangan untuk membuat kebijakan, baik kebijakan strategis maupun kebijakan teknis seperti kepala Dinas, sekretaris atau kepala bagian. 
3. Tokoh Masyarakat yang sering terlibat dalam proses pembuatan kebijakan pemda KBB.

4. Tokoh Media

Validasi data dilakukan dengan menggunakan metode triangulasi, yaitu mengkonfirmasi ulang semua data yang diperoleh kepada para informan sehingga diperoleh derajat data yang jenuh (saturated data). Selain itu, triangulasi juga dilakukan kepada para ahli pembuat kebijakan dan ahli komunikasi politik pemerintah, sebagai upaya mengkonfirmasi temuan data yang ada.

Data yang diperoleh dari hasil wawancara mendalam, observasi dan studi dokumentasi serta Focuss Group Discussion kemudian diolah dengan cara dibuat transkrip dan dikategorisasikan sesuai kebutuhan. Kemudian data tersebut dianalisis dengan menggunakan teori dan konsep-konsep komunikasi politik pemerintah, sehingga dapat diambil kesimpulan. Proses analisis data dilakukan sejak awal masa pengumpulan data hingga akhir saat pembuatan kesimpulan. Artinya proses analisis data dilakukan sepanjang proses pengumpulan data berlangsung.

\section{HASIL DAN PEMBAHASAN}

Dari hasil pengumpulan data di lapangan berupa observasi dan wawancara mendalam serta Focuss group Discussion (FGD), diperoleh beberapa gambaran sebagai berikut:

\section{Persiapan menghadapi MEA}

Merujuk pada dokumen yang kami terima dari pemda KBB saat penelitian lapangan, aparat pemerintah daerah KBB mengklaim bahwa MEA sudah cukup mendapat perhatian. Hal ini setidaknya dapat dilihat dari adanya kegiatan yang dilakukan pemda KBB bekerjasama dengan Universitas Pasundan yang sejak tahun 2009 melakukan sosialisasi MEA dengan sasaran para pelajar tingkat SMA (Sekolah Menengah Atas), SMK (Sekolah Menengah Kejuruan) \& MA (Madrasah Aliyah) di wilayah KBB.

Salah satu informan dalam penelitian ini Kun Kunrat, tokoh masyarakat KBB yang juga dosen Universitas Pasundan mengemukakan bahwa sosialisasi dikemas dalam bentuk simulasi sidang ASEAN berbahasa Inggris di kota Bandung. Kegiatan ini kemudian berlanjut dengan pemda provinsi Jawa Barat, (termasuk didalamnya pemda KBB) dengan anggaran sebesar 2 Milyar yang dialokasikan dalam APBD pemprov Jabar dan ini melibatkan 67 lembaga Pendidikan menengah atas.

"Jadi tentang MEA ini sebetulnya untuk kalangan pelajar se Jawa Barat sudah dilakukan sosialisasi, hanya mungkin bagi birokrat di KBB informasi MEA belum begitu kuat." (data FGD tanggal 17 November 2017 di Hotel Vio Bandung).

Peneliti mencermati pernyataan Kun Kunrat bahwa sosialsiasi MEA sudah dilakukan kepada segmen pelajar dan mahasiswa, sebetulnya belum dapat dikatakan sebagai sosialisasi yang tepat sasaran. Karena dalam konteks MEA, stakeholders utama adalah para pelaku ekonomi seperti pengusaha, para professional dan tenaga kerja terampil. Seharusnya yang menjadi target utama sosialisasi MEA adalah kelompok ini terlebih dahulu, kelompok pelajar dapat dijadikan sasaran berikutnya. Secara konseptual seperti dikemukakan (Black, 2000), tujuan komunikasi politik pemerintah adalah memberitahukan kepada masyarakat apa yang seharusnya mereka ketahui. Maka dalam konteks MEA, memberitahukan segala sesuatu tentang peluang dan tantangan MEA tentu lebih utama disampaikan kepada stakeholder utama yakni pelaku ekonomi.

Sementara itu, secara umum, baik dinas Perindustrian \& Perdagangan (Disperindag) maupun Dinas Komunikasi \& Informasi (Diskominfo) pemda KBB menyatakan belum memiliki strategi khusus untuk menghadapi MEA. Hal ini dikemukakan oleh kepala Dinas Komunikasi \& Informasi Ludi Awaludin,

"kalau saya baca kondisi di masyarakat secara langsung nampaknya masyarakat belum memahami betul apa itu MEA. Tetapi dinamikanya sudah nyampe. Contohnya saya melihat di media-media social, potensi pariwisata KBB sudah sering muncul, terutama Lembang. Padahal pemerintah tidak secara khusus melakukan sosialisasi MEA, tapi potensi pariwisata KBB sudah sampai ke masyarakat di luar negeri."

Dadang Harisudin, sekretaris Disperindag KBB juga menyatakan hal yang sama dengan Kadiskominfo, bahwa sosialisasi khusus tentang MEA belum ada, tetapi pada setiap kegiatan dan program kerja Disperindag kemasyarakat, selalu ditekankan tentang pentingnya peningkatan kualitas karena sedang menghadapi pasar bebas Asean.

"sosialisasi MEA sudah pernah diselenggarakan oleh provinsi, di gedung Sate tempatnya. Di internal kita dilaksanakan oleh bagian perekonomian. Karena kan dinas yang terkait MEA teh banyak, ada dinas perindustrian, pariwisata, ketenagakerjaan, perdagangan, dan koperasi juga masuk karena ada UMKMnya."

Sosialisasi MEA dari pemerintah provinsi kepada pemerintah kota kabupaten diakui Dadang sudah dilaksanakan sejak tahun 2015.

"setiap kita melakukan kegiatan ke masyarakat, misalnya pelatihan segala macem itu kita sampaikan tentang MEA, jadi kegiatan apapun dikaitakan dengan isu MEA. Misalnya kenapa harus meningkatkan daya saing produk, Karena kita bersaing dengan produkproduk dari luar, dari negara-negara ASEAN"

Dari tiga pernyataan di atas, secara eksplisit para informan memberikan pengakuan tentang belum adanya sosialisasi khusus tentang MEA kepada masyarakat. 
Maka jika merujuk pada konsep komunikasi politik pemerintah, masyarakat KBB belum mendapatkan haknya memperoleh informasi tentang MEA karena pemerintah KBB belum melakukan sosialisasi secara sistematis dan terarah.

Walaupun, pernyataan Dadang Harisudin dikuatkan dengan adanya kegiatan "Rapat Koordinasi Kesiapan Menghadapi Masyarakat Ekonomi Asean di Lingkungan Pemerintah Kabupaten Bandung Barat" yang. diselengarakan tanggal 13 Oktober 2015 di Hotel Takashimaya Lembang, tidak berarti rapat koordinasi yang hanya satu kali ini sudah menggugurkan kewajiban pemerintah memberi tahu masyarakat tentang MEA.

Temuan penelitian lainnya terungkap bahwa dalam rapat koordinasi tersebut, asisten bidang Perekonomian dan Pembangunan Sekretaris Daerah KBB menyampaikan beberapa formulasi dukungan daerah yang diperlukan dalam menghadapi tantangan MEA, tetapi peneliti mencermati, pada prakteknya formulasi tersebut belum diejawantahkan secara konkrit.

Secara rinci hasil rapat tersebut menyatakan bahwa bentuk formulasi dukungan daerah KBB dalam menghadapi tantangan MEA antara lain:

A. Strategi publikasi yang intensif dan menyeluruh, yang meliputi:

> Publikasi tentang MEA yang lebih luas, menggunakan media cetak, media elektronik (terutama TV yang dapat menjangkau masyarakat kelas menengah bawah), dan jejaring sosial;

$>$ Publikasi yang bersifat edukatif (tidak bersifat negatif), dengan materi yang disesuaikan dengan target group nya;

$>$ Mendorong masyarakat untuk memanfaatkan peluang MEA, bukan untuk menghindari MEA;

> Mendirikan pusat layanan informasi MEA daerah.

B. Strategi Peningkatan Daya Saing Daerah, mencakup:

- Membenahi kemudahan perizinan usaha dan menurunkan biaya rente ekonomi (seperti: pungutan liar dan biaya birokrasi lainnya);

- Perbaikan infrastruktur (seperti: jalan dan pelabuhan); w

- Perbaikan kualitas aparatur daerah;

- Harmonisasi regulasi dan penyederhanaan peraturan.

C. Strategi Peningkatan Peran UKM meliputi:

- Fasilitasi promosi dagang untuk UKM di kawasan ASEAN

- Pelayanan informasi akses pasar dan prosedur ekspor kawasan ASEAN;

- Mengadakan pelatihan untuk meningkatan kualitas produk UKM;

- Memfasilitasi UKM dalam memperluas akses pendanaan.

D. Strategi Lainnya, berupa:

$\checkmark$ Mempromosikan destinasi pariwisata dengan lebih aktif dan mandiri; $\checkmark$ Bekerja sama dengan akademisi terkait pembekalan tenaga kerja siap kerja;

$\checkmark$ Koordinasi intensif antara pemerintah pusat dan daerah

Bahkan dalam rapat koordinasi tersebut, pemda KBB menyimpulkan bahwa dalam menghadapi tantangan MEA di tahun 2016, harus dilakukan beberapa hal penting, seperti:

1) Meningkatkan Daya Saing (Competitive Advantage);

2) Membenahi Infrastruktur;

3) Mendorong tumbuh kembangnya Ekonomi Kreatif;

4) Regulasi harus mendorong pertumbuhan dan penguatan ekspor;

5) Mengurangi/ menghapus Biaya ekonomi tinggi;

6) Meningkatkan pertumbuhan diversifikasi ekspor industri bukan seperti sekarang didominasi ekspor bahan baku;

7) Membuat prioritas dalam mencintai produk dalam negeri. (sumber: Materi presentasi dalam bentuk Power point oleh Asisten bidang Perekonomian \& Pembangunan KBB pada rapat koordinasi Persiapan MEA tanggal 13 Oktober 2015.)

Selain tekad pemda KBB yang disimpulkan dalam rapat koordinasi tersebut, Dadang Harisudin menambahkan bahwa untuk meningkatan kualitas produk salah satunya dengan membuat inovasi-inovasi produk yang khas menjadi identitas KBB, seperti batik Oncom. kendati belum sampai di ekspor, tetapi pemasaran local sudah mulai tinggi.

"semua produk dan inovasi selalu kami himbau agar didaftarkan HKI dan SNI nya, karena yang memiliki nilai jual tinggi harus produk yang sudah berSNI."

Kebijakan pemerintah pusat dalam standar produk yang menwajibkan melalui sertifikasi berupa SNI dan bahkan pendaftaran Kekayaan Intelektualnya ini hanya sanggupdilakukan oleh pemda KBB berupa himbauan, mengingat para produsen yang ada di KBB kebanyakan masih dalam kategori skala industry kecil bahkan industri rumahan.

Hal ini dibenarkan oleh Asep, salah seorang staf Dinas Perindustrian dan Perdagangan KBB dalam wawancara denan peneliti,

"iya kalau soal SNI dan HKI masih banyak yang belum sanggup, karena keterbatasan kemampuan biaya dari para produser. Sementara kami dari Indag kan sifatnya hanya bisa memfasilitasi, belum bisa menanggung biaya." (Wawancara dengan informan Asep, tanggal 8

November 2017 di kantor Disperindag KBB).

Walaupun menghadapi berbagai keterbatasan, dikemukakan Dadang Harisudin bahwa di luar negara ASEAN, KBB ternyata malah sudah menyasar pasar Timur Tengah, dengan mengeskpor cendera mata berupa miniature binatang-binatang ke negara Arab. Sedangkan 
industri Agro mencakup makanan dan minuman berupa obat herbal berbahan dasar Jahe. Sementara pasar local meliputi: kerupuk Gurilem, Ikan Pepetek, Susu Murni dan sayur mayur seperti wortel.

Dari wawancara dengan sekretaris Disperindag ini nampak bahwa sosialisasi MEA belum dilakukan dengan menggunakan strategi khusus, mereka hanya focus pada tugas pokok fungsi (tupoksi) yakni memfasilitasi dinas pertanian dan dinas koperasi \& UMKM untuk memasarkan produk-produk yang ada di masyarakat kepada para stakeholder.

"jadi kan gini, secara umum nanti ada MEA itu apa saja kan produknya harus jelas, nah yang melaksanakan instansi terkait misalnya produk pertanian kalua diolah jadi industry, misalnya kentang jadi keripik. Nah Disperindag memfasilitasi, misalnya dengan cara ikut pameran di tingkat kabupaten, provinsi maupun nasional seperti inna craft. Dengan ikut pameran kita juga jadi punya pengetahuan kualitas dan ragam jenis barang dari daerah lain dan negara lain. Terutama barang dari China, kita amati kenapa bias bagus tapi murah" (Wawancara dengan sekretaris Disperindag, tanggal 17 Juni 2017 di kantor Diseprindag KBB).

Dari paparan data hasil wawancara mendalam dengan para informan tentang persiapan KBB menghadapi MEA, peneliti mencermati bahwa secara tekstual, pemerintah KBB sudah membuat formulasi strategi komunikasi pemerintah dalam menghadapi MEA, namun secara praktikal belum dilaksanakan dengan optimal.

Misalnya, ada strategi komunikasi dengan cara membuat publikasi tentang MEA menggunakan media cetak, media elektronik (terutama TV yang dapat menjangkau masyarakat kelas menengah bawah), dan jejaring sosial; tetapi pada prakteknya belum ada satupun yang dilaksanakan.

Begitu juga dengan rencana membuat publikasi yang bersifat edukatif (tidak bersifat negatif), dengan materi yang disesuaikan dengan target group, baru sebatas konsep di atas kertas, belum ada satupun dinas atau instansi yang melaksanakannya. Seperti halnya rencana mendirikan pusat layanan informasi MEA daerah, suatu rencana yang sangat ideal sebetulnya, saying belum direalisasikan.

\section{Sosialisasi MEA}

Data lapangan juga menunjukkan pemerintah KBB belum banyak melakukan sosialisasi secara khusus tentang MEA, padahal secara khusus tugas menyosialisasikan MEA baik kepada masyarakat umum maupun kepada seluruh karyawan berada di wilayah kerja Asisten Bidang Perekonomian \& Pembangunan.

Dikemukakan informan Asep dari Disperindag bahwa dinasnya berusaha menyosialisaskan industri Kecil dan Menengah (IKM) yang ada di KBB agar dapat mulai dikenal oleh negara anggota komunitas Asean yang kebetulan berkunjung ke daerah tujuan wisata yang ada di KBB, salah satunya dengan mewajibkan ritel-ritel di trempat-tempat wisata untuk menjual dan memajang produk-produk IKM.

Terkait dengan media sosialisasi, Disperindag sendiri seperti dinyatakan Harisudin, hanya mengandalkan media massa sebagai media komunikasi khusus untuk menyosialisasikan apapun termasuk MEA.

"kami tidak banyak menggunakan medsos, ada website tapi ikut ke website KBB, bukan khusus Disperindag. Begitu juga twiter atau facebook, kita ga pake. Ada sih grup whatsap, tapi itu dibuat oleh grup komunitas, misalnya grup para pengusaha kuliner, Disperindag ikut di grup tersebut dalam kapasitas pembina, ada juga grup wahtsap Forum UMKM."

Di tengah masivnya penggunaan social media di kalangan masyarakat dan swasta, nampaknya pemerintah KBB belum tertarik menggunakan media social sebagai media komunikasi khususnya sosilisasi MEA, seperti dinyatakan Harisudin,

"kami cukup menggunakan wartawan pokja saja, kasih press release ke mereka, selesai deh"

Berbeda dengan Dispreindag, Diskominfo nampak lebih variatif menggunakan berbagai media sebagai saluran informasi, seperti dikemukakan kepala Dinas Kominfo Ludi Awaludin,

"kita sudah ada $e$-govt, jadi itu yang kita maksimalkan untuk menghadapi MEA. Aplikasi informatika di pemerintahan ini mempunyai tiga fungsi, pengembangan penyelenggaraan pemerintahan dengan pemerintahan, pemerintah dengan kalangan bisnis dan pemerintah dengan warga negara atau masyarakat. Termasuk supporting ke dinas-dinas lain."

Support untuk dinas lain tersebut dijelaskan Awaludin misalnya bagaimana mengembangkan bisnis online untuk 1000 UMKM di KBB, dimana para pengusaha UMKM ini dilatih untuk bisa akses ke dunia maya.

"dengan masyarakat kita melakukan upaya edukasi, seperti pemanfaatan digital, sosmed, semoga mereka bias memilah mana yang positif mana yang negative. Ada juga lokakarya dan sosialisasi ke sekolah-sekolah tapi tidak khusus dengan content MEA."

Awaludin juga menyatakan bahwa Kominfo lebih banyak mendukung dinas-dinas lain, melalui tiga bidang yakni yang pertama infrastruktur dan teknologi, kedua, aplikasi dan management data serta ketiga e-govt. Salah satu andalan Kominfo adalah website KBB yang dikelola langsung oleh dinas Kominfo.

"website di bawah IKP (Informasi Komunikasi \& Publikasi), anak-anak IKP yang membuat konten nya. Kita harapkan website kita kaya dengan 
informasi, untuk misi terdekatnya. Iconnya adalah smart city. "

Dari paparan data hasil observasi dan wawancara mendalam dan FGD dengan para narasumber, peneliti mencermati, MEA belum menjadi isu utama dalam program kerja pemerintah KBB. Kendati mereka menyatakan tahu tentang MEA, tetapi nampak sebetulnya belum paham secara rinci bagaimana MEA bekerja. Hal ini terlihat dari masih gamangnya para aparat menjawab tentang bagaimana upaya mereka menyosialisasikan MEA. Jawaban yang diberikan lebih bersifat teknis pekerjaan yang biasa mereka lakukan yang sama sekali tidak dalam konteks MEA dan tidak berupa jawaban strategis, walaupun yang menjawab adalah seorang kepala Dinas.

Dari hasil FGD, narasumber utama Moh. Rizky Safari Kasubdit Kerjasama Asean bidang internal dan eksternal Kementerian Luar Negeri RI menilai bahwa nampaknya pemerintah KBB sudah cukup tanggap terhadap tantangan dan peluang MEA ini, buktinya sudah pernah dilakukan rapat koordinasi tentang hal ini.

"kalau saya lihat, pemda KBB sudah terlihat ada upaya mempersiapkan diri menghadapi MEA sejak tahun 2015. Dimulai dengan rakord2 mungkin ya? Lalu pernah juga ikut sosialisasi Asean yang diselenggarakan oleh Pemprov Jabar. Tetapi perlu dicermati lagi apakah sudah ada regulasi khusus yang mengatur tentang strategi menghadapi MEA. Kalua memang sudah ada, berarti langkah selanjutnya pemda KBB harus mulai berani membuka akses pasar ke negara-negara Asean untuk mulai mengaktifkan kegiatan perdagangan luar negerinya." (M. Rizky Safari, Kasubdit Bidang Kerjasama Asean Kemenlu RI dalam FGD tanggal 17 November 2017).

Lebih jauh menurut M. Rizky Safari, pemda KBB harus sanggup memanfaatkan peluang negosiasi dengan negara lain di Asean. Oleh karenanya diperlukan adanya Policy Design yang dibuat oleh pemda KBB khusus untuk menghadapi peluang dan tantangan MEA.

"Kalau sampai pemda KBB menyertakan ASEAN dalam Visi Misinya, maka itu sesuatu yang hebat."

Diungkapkan Rizky, Kemenlu memiliki tupoksi untuk sosialisasi komunitas Asean ke sekolah-sekolah, kampus, pengusaha, dan semua stakeholders. tetapi karena terkendala anggaran, sosialisasi tidak bias massif. Itu sebabnya pemerintah daerah seharusnya aktif melakukan sosialisasi MEA secara mandiri.

"karena masyarakat harusnya dapat memanfaatkan peluang MEA, terutama investasi, sehingga dengan AFTA yg zero tarif, seharusnya produk2 kita bias membanjiri negara-negara lain. Walaupun saya akui bahwa sejak 1990-2004, masyarakat kita memang tidak disiapkan untuk AFTA, jadi bukan tidak siap, tapi memang tidak disiapkan. "(M. Rizky Safari, Kasubdit Bidang Kerjasama Asean Kemenlu RI dalam wawancara triangulasi tanggal 12 Oktober 2017).

Menurut Rizki, fungsi strategis Kemenlu sendiri adalah membuka kunci pintu-pintu dengan negara lain agar dapat dimanfaatkan oleh daerah. Bahkan pada era presiden Soesilo Bambang Yudhoyono, bidang ekonomi (Trade), Tourism \& Investment sudah mulai di genjot.

"Jadi Kemenlu hapal betul dengan kondisi di setiap negara, sehingga dapat dimanfaatkan oleh daerah. Masalahnya pemda juga jarang ada yang mau berkomunikasi dengan kami, sementara keterbatasan anggaran di kementerian kami juga menjadi kendala untuk kami bias mendatangi daerah yang jumlahnya hamper 500 unit di seluruh Indonesia. Kemampuan kami paling dalam satu tahun hanya 12 kali melakukan sosialisasi di daerah."

Terkait MEA, ada beberapa issue krusial yang perlu mendapat perhatian pemerintah, antara lain tentang standarisasi.

"Standar barang-barang untuk ekspor sudah ada di AFTA dalam bentuk kesepakatan di tingkat Menteri, makanya secara teknis kewenangan menentukan standar ada di kementerian-kementerian. Di sisi lain Pemda harusnya paham dengan kondisi daerahnya masing-masing, kemudian dioptimalkan oleh biro kerjasama luar negeri, nah KBB punya nggak biro ini?"

Dijelaskan Rizky, potensi Indonesia dibandingkan negara lain sebetulnya jauh lebih bagus negara Indonesia, oleh karenanya peluang MEA ini justru harusnya lebih banyak dimanfaatkan oleh negara Indonesia.

"contohnya Singapore, mereka punya apa? Bisa ambil manfaat apa dari MEA? Ga ada. Justru kita yg sebetulnya punya banyak peluang. Deplu siap buatkan template policy design untuk pemda-pemda. Salah satu peran pemda itu mendorong komersialisasi hasil riset dan KBB harus tahu persis produk unggulannya apa? Seperti di Thailand, 1 kecamatan punya 1 produk unggulan".

Sejalan dengan Rizky, ketua Kamar Dagang Indonesia (Kadin) KBB, Ade Khaerudin juga menyatakan bahwa yang paling dibutuhkan oleh para pelaku ekonomi di KBB adalah adanya keberpihakan dan fasilitasi pemerintah KBB kepada para pengusaha terutama pengusaha lokal KBB.

"keberpihakan itu misalnya regulasi-regulasi yang memudahkan investasi di KBB, atau membuka akses pasar ke negara-negara luar." (Ade Khaerudin, ketua Kadin KBB, dalam wawancara tanggal 3 November 2017). 
Menurut Ade, dirinya mencermati bahwa secara realistis KBB nampaknya belum siap hadapi MEA, padahal sebetulnya potensi KBB itu cukup banyak, tapi pemdanya belum bisa explore. Oleh karenanya, dalam upaya meningkatkan kualitas SDM masy KBB menghadapi MEA, Kadin sendiri mencoba turut berkontribusi dengan melakukan pembinaan kepada 120 siswa-siswa SMK di KBB.

"Selain itu pekerja yang lulusan SMP diberi rekomendasi agar diijinkan oleh perusahaannya untuk ikut sekolah sabtu minggu."

Kadin KBB kendati kepengurusannya baru dua periode, Nampak cukup antusias menegaskan perannya dalam kiprah ekonomi KBB. Salah satunya dapat dilihat dari aktivitas Kadin KBB yang bekerjasama dengan Universitas Komputer (Unikom) ikut memberikan materi kewirausahaan pada para mahasiswa, agar punya wawasan secara praktikal tentang wirausaha.

"Itu kami lakukan karena kami paham betul meningkatkan kualitas SDM harus melalui Pendidikan, sementara KBB belum punya universitas, jadi wajar kaluau SDM nya masih lemah."

Selain membantu meningkatkan kapasitas Sumber Daya Manusia, menurut Ade, langkah strategis juga dilakukan dengan cara Kadin memfasilitasi konsultasi perusahaan tentang kegiatan CSR agar lebih efektif.

"Dan itu dilakukan secara mandiri oleh Kadin KBB tanpa ada bantuan dana dari pemda. Padahal layaknya Kadin itu menjadi mitra Pemda, apalagi sebetulnya Kadin yang lebih tahu kondisi di lapangan dibandingan dengan pemda. Apa yg dibutuhkan masyarakat dan pengusaha itu datanya ada di Kadin bukan di pemda. Tetapi memang Kadin merasa malas kerja sama dengan pemda karena birokrasi yang berbelit dan adanya perbedaan paradigma. Paradigm Kadin sebagai pengusaha sementara pemda sebagai birokrat, ya susah untuk bias nyambung."

Menurut Ade, seharusnya Kadin tahu apa yang direncanakan pemda KBB dalam konteks MEA, karena Kadin dapat menjadi jembatan antara investor dengan pemda. Tetapi nampaknya sejauh ini pemda belum melakukan sosialisasi tentang MEA baik ke pengusaha yg ada dalam wadah Kadin ataupun ke stakeholder yang lain.

"Jadi Kadin nya saja yg aktif sendiri mencari info tentang MEA. Padahal harusnya pemda dan Kadin dapat berkomunikasi dengan baik. Misalnya untuk menggarap potensi wisata industry dan pariwisata, harus sejalan dulu antara pengusaha dengan pemerintah. Tapi Tahun ini di KBB sedang panas karena menjelang pilkada, jadi Kadin agak menjaga jarak dulu. Ini berbeda karena Kadin yang lama lebih banyak meminta proyek ke pemda, dan imbalannya memberikan dukungan politik pada penguasa. Sekarang ini kami tidak mau begitu, Kadin harus professional dan mandiri, dan tidak terlobat dengan praktek politik kotor. Karena Kadin adalah organisasi yg dibentuk oleh UU, dimana semua organisasi bisnis harus menjadi anggota ikadin. Artinya semua pelaku ekonomi wajib menjadi anggota Kadin. Saat ini anggota Kadin KBB baru ada 75 dari berbagai sector usaha, mulai manufaktur, tekstil, UMKM, dll. Sehingga, menghadapi situasi seperti ini, kami berpikir dengan terobosan pemikiran, jika ada pengusaha anggota Kadin menjadi kepala daerah, maka nampaknya KBB bisa lebih mempersiapkan diri dalam menghadapi MEA, karena kan orang Kadin mah apal medan." (Ade Khaerudin, ketua Kadin KBB, dalam wawancara tanggal 3 November 2017).

Pada intinya, Kadin KBB berpandangan bahwa Pemda itu harus punya peta tentang para pengusaha di KBB, pengusaha local mana dari luar KBB. Saat ini yang banyak beraktivitas bisnis di KBB justru bukan pengusaha asli $\mathrm{KBB}$, tetapi kebanyakan investor dan pengusaha dari Jakarta. Bukan berarti menolak yang dari luar, tetapi pemda KBB harus lebih memprioritaskan yang dari dalam KBB.

\section{SIMPULAN}

Dari data yang diperoleh di lapangan serta analisis, dapat disimpulkan bahwa pemerintah KBB belum mempunyai strategi sosialisasi khusus terkait Masyarakat Ekonomi Asean. Upaya pengkomunikasian MEA baru dilakukan oleh Dinas Komunikasi dan Informasi yang sedang berusaha melengkapi perangkat organisasinya agar dapat mengoptimalkan dukungan bagi dinas-dinas lain terutama dengan menggunakan teknologi informatika. Adapun media komunikasi dan sosialisasi yang digunakan saat ini adalah website dan kelompok kerja wartawan. Sejauh ini, content MEA belum disampaikan secara eksplisit dan rinci dalam kegiatan pelatihan-pelatihan bagi pelaku ekonomi di KBB, tetapi hanya diselipkan bahwa kita harus siap menghadapi MEA tanpa merinci bagaimana caranya dan apa itu MEA serta dampaknya dalam kehidupan perekonomian masyarakat KBB, oleh karenanya perlu ada penguatan informasi di kalangan internal apparat pemda KBB tentang segala sesuatu menyangkut MEA.

\section{UCAPAN TERIMA KASIH}

Artikel ini merupakan hasil penelitian yang dibiayai oleh dana Hibah Internal Unpad (HIU) dengan skema Riset Fundamental Unpad (RFU) tahun 2017. Untuk itu kami menyampaikan terimakasih kepada rektor Unpad melalui Direktorat Penelitian, Pengabdian Masyarakat \& Inovasi (DRPMI) yang telah memberi kesempatan 
pada kami untuk membuat penelitian ini. Selain itu kami juga menghaturkan terima kasih kepada redaksi jurnal Sosiohumaniora yang telah berkenan memuat hasil riset kami ini.

Kami juga ingin menyampaikan terima kasih kepada para narasumber riset dari Dinas Perindustrian \& Perdagangan, Dinas Komunikasi \& Informasi, dan Dinas Tenaga Kerja pemerintah Kabupaten Bandung Barat. Juga kepada narasumber triangulasi yaitu Kasubdit Kerjasama Regional \& Internasional Kementreian Luar Negeri RI Mohamad Rizky Safari, Ketua Kamar Dagang Indonesia KBB Ade Khaerdudin dan Tokoh Masyarakat KBB Drs. Kun Kunrat M.Si.

\section{DAFTAR PUSTAKA}

Razak, A. dan Elyta. (2017) Faktor Penghambat Kerajinan Anyaman Tangan Di Perbatasan Sajingan Besar Dalam Menghadapi Masyarakat Ekonomi Asean, Sosiohumaniora, Vol. 19(3): 213 -217
Creswell, J.W. (1998). Qualitative Inquiry and Research Design. California: Sage.

Creswell, J.W. (2012). Research Design: Pendekatan Kualitatif, Kuantitatif, dan Mixed. Yogyakarta: Pustaka Pelajar.

Departemen Perdagangan RI. (2015). Buku Menuju ASEAN Economic Community. Jakarta.

Masyarakat ASEAN, edisi 15/ April 2017, Kementerian Luar Negeri Republik Indonesia. Jakarta.

McNair, B. (2007). An Introduction to Political Communication. London: Routledge.

Mingkid, E. (2015). Penggunaan Media Komunikasi Promosi Pariwisata Oleh Pemerintah Kota Manado, Sosiohumaniora, Vol. 18 (3): 188192

Nimmo, D. (2005). Komunikasi Politik: Komunikator, Pesan dan Media. Bandung: Remaja Rosda Karya 